11. Guyot, Y. A three-dimensional computational fluid dynamics model of shear stress distribution during neotissue growth in a perfusion bioreactor [Text] / Y. Guyot, F. P. Luyten, J. Schrooten, I. Papantoniou, L. Geris // Biotechnology and Bioengineering. 2015. - Vol. 112, Issue 12. - P. 2591-2600. doi: 10.1002/bit.25672

12. Копиленко, А. В. Сучасна концепція моделювання гідродинаміки в ролерному біореакторі з поверхневим культивуванням клітинних культур [Текст] / А. В. Копиленко, С. М. Семенюк, В. Ю. Шибецький, С. І. Костик // Наукові праці НУХТ. - 2017. - Т. 23, № 2. - С. 114-122.

13. Костик, С. І. Математичне моделювання гідродинаміки перемішуючого пристрою з магнітним приводом [Текст]/ С. І. Костик, Л. І. Ружинська, В. Ю. Шибецький, О. О. Ревтов // ScienceRise. - 2016. - Т. 4, № 2 (21). - C. 27-31. doi: $10.15587 / 2313-8416.2016 .67275$

14. Gelbgras, V. Segregated Model of Adherent Cell Culture in a Fixed-Bed Bioreactor [Text] / V. Gelbgras, C. E. Wylock, J.-C. Drugmand, B. Haut // Chemical Product and Process Modeling. - 2011. - Vol. 6, Issue 1. doi: 10.2202/1934-2659.1522

Рекомендовано до публікації д-р техн. наук Мельник В. М. Дата надходження рукопису 23.05.2017

\begin{abstract}
Шибецький Владислав Юрійович, кандидат технічних наук, старший викладач, кафедра біотехніки та інженерії, Національний технічний університет України «Київський політехнічний інститут ім. Ігоря Сікорського», пр. Перемоги, 37, м. Київ, Україна, 03056

Семенюк Сергій Миколайович, кафедра біотехніки та інженерії, Національний технічний університет України «Київський політехнічний інститут ім. Ігоря Сікорського», пр. Перемоги, 37, м. Київ, Україна, 03056

E-mail: sem2mn@gmail.com
\end{abstract}

Костик Сергій Ігорович, кандидат технічних наук, асистент, кафедра біотехніки та інженерії, Національний технічний університет України «Київський політехнічний інститут ім. Ігоря Сікорського», пр. Перемоги, 37, м. Київ, Україна, 03056

E-mail: kostyksergey@ukr.net

UDC: $664.1-663$

DOI: 10.15587/2313-8416.2017.107207

\title{
RESEARCH OF INFLUENCE OF BIOLOGICAL ACTIVATION ON THE VITAMIN COMPLEX OF GRAIN CEREAL CULTURES
}

\author{
(C) S. Bazhay-Zhezherun, L. Bereza-Kindzerska, O. Togachynska
}

Запропоновано режим гідротермічного оброблення зерна злакових культур - пшениці, голозерного вівса, тритикале, який сприяє підвищенню його харчової цінності, зокрема збільшення кількості вітамінів, шляхом біологічного активування. У прочесі запропонованої підготовки зерна суттєво знижується вміст антимінеральної речовини фітину, значно зростає вміст вітамінів антиоксидантів, вітамінів групи В, інозиту

Ключові слова: біологічне активування, пророщене зерно, вітаміни, пшениця, голозерний овес, тритикале

\section{Introduction}

Sprouting grains, as a method for biological activation, used to increase the nutritional value of grain and other of raw materials.

Germinated grain of wheat that contains plant protein, it is recommend to include in a diet for the purpose of the general strengthening of an organism and, in particular, enhance or restore of sexual activity [1], reduction to risk of emergence and development of oncological diseases [2], enrichment of an organism of children of biologically active substances [3]. The consumption of sprouted grains improves reproductive function [4]. Important question is the research of influence of reasonable parameters of germination process on change of content of a vitamin complex of the main grain crops wheat, oats, triticale.

\section{Literature review}

Germinated grain has high nutrition value. Scientists investigated that total content of antioxidants in germinated grain are higher at 3-10 times (depending on culture) compared with native grain. Regular consumption of germinated grain stimulates a metabolism, blood formation, increases immunity, compensates vitamin and mineral deficiency, normalizes acid-base balance, promotes cleaning of an organism of slags, effective digestion, raises a potentiality, slows down processes of aging [5].

In domestic and foreign scientific literature it is noted that the content of vitamins is increased during germination of grain [6]. Scientists note that the content of $\mathrm{B}$ group vitamins, in particular, $\mathrm{B}_{1}, \mathrm{~B}_{2}, \mathrm{~B}_{5}, \mathrm{~B}_{6}$ at 5-10 times higher in wheat sprouted grain than in mature. Also 
during germination of grain wheat vitamin $\mathrm{C}$ is synthesized [7]. It is established that after biological activation of grain wheat during the 24 hours the content of vitamins $\mathrm{B}_{2}$ and $\mathrm{B}_{6}$ increases by 26 and $65 \%$, the content of vitamin $\mathrm{E}$ increased in 6,5 times, the amount of nicotinic acid (PP) increased by 1,3 times [8, 9]. Scientists noted that the maximum increase in contents of folic acid by 3,6 times in germinated grain of wheat and 1,7-3,8 times in rye is recorded for the fifth time of germination, the quantity of carotinoids is the highest for the seventh day of germination [10, 11]. During of germination of such valuable grain crops as triticale and oats authors did not investigate accumulation of vitamins.

It is known that a phytic acid forms insoluble calcium salts that are not digested by the digestive juice [12]. Therefore, the presence of phytin in foods is not desirable. The scientists developed methods of phytin selection from grain raw materials and waste of its redoing $[13,14]$. However, the degree of hydrolysis of phytin in the course of biological activation of grain authors is not revealed. The accumulation of an inositol in the soaking and sprouting grains also not investigated.

Insufficient study of influence of biological activation at the concrete reasonable modes of grain of valuable cereal cultures of wheat, bare grain oats and triticale on change of content of all main vitamins and extent of hydrolysis of phytin proves need of carrying out researches for this direction.

\section{Aim and problems of research}

The aim of research is establishment the impact of the biological activation of grain cereal crops wheat, oats and triticale by hydrothermal processing of the change content of essential vitamins and degree of hydrolysis phytin. solved:

For achievement of a goal the following tasks are

- define indicators of the physiological values of grain: energy and the ability to germination, the viability of the grain and water sensitivity;

- investigate the degree of hydrolysis phytin and the accumulation of inositol in the process of the biological activation grain;

- investigate the influence of the biological activation of grain on change of content vitamins, which have an antioxidant properties - tocopherol, ascorbic acid, vitamin P, vitamins of group B and niacin.

4. Materials and methods of research of biological activation influence of grain wheat, triticale and oats depending on change of content vitamins

Samples of grain wheat, triticale and bare grain oats, respectively, grades Myronivska 137, Alkid, Solomon were used for research.

Indicators of physiologic value of grain were defined according to techniques [15].

Phytin is determined by extraction it from grain $1-\%$ solution of nitric acid and further sedimentation by $25-\%$ solution of ammonia. The besieged phytin was filtered and dried up in a drying cabinet at $80{ }^{\circ} \mathrm{C}$ for 10 hours [13]. The inositol was determined by method of a highly effective liquid chromatography, which included the freeze-drying and milling of the sample, extraction of $0,5 \mathrm{M}$ hydrochloric acid, a decantation, filtering of a decantate under pressure and actually a chromatography on a chromatography of PERCIN ELMER. Definitions were carried out with use of the ultraviolet detector $(\lambda=325 \mathrm{~nm})$.

Definition of vitamin $\mathrm{C}$ was carried out by a titration method [16]. From grain vitamin $\mathrm{C}$ was extracted $2-\% \mathrm{HCl}$ solution. Contents were maintained during 10 minutes and filtered. The received extracts titrated by solution of sodium 2,6-dichloropheno-lindophenolate to the appearance of weakly pink color. For definition of vitamin $\mathrm{P}$ to $1 \mathrm{~g}$ of a sample added $40 \mathrm{ml}$ of $2 \% \mathrm{KOH}$ solution and heated on the boiling water bath with the return refrigerator of 15 minutes. The received extract was cooled and filtered. Optical density was measured of the solution on the photocolorimeter at a wavelength about $500 \mathrm{~nm}$ in cuvette with a layer thickness of $5 \mathrm{~mm}$. Control solution was distilled water [16]. Definition of vitamin $\mathrm{E}$ is based on formation of quinone during oxidation of tocopherol molecules, extractable from studied sample, by chlorine iron. There is a recovery of chlorine iron to chlorous which quantity is defined behind intensity of a coloring during addition of orthophenanthroline [16].

For choline determination, sample was hydrolyzed in the presence of $20 \% \mathrm{HNO}_{3}$ on the boiling water bath. To the filtrate, neutralized $33 \%$ alkaline solution (pH 10), was added $2 \%$ solution of chromthiocyanate salt and left for 18 hours in the refrigerator. The formed precipitate was filtered, washed with n-propanol at $0{ }^{\circ} \mathrm{C}$ and was dissolved in acetone. The resulting solution is calorimetry on the FEC-56M, ( $\lambda=510-540 \mathrm{~nm})$. Control solution was acetone [16].

Vitamin $B_{1}$ is determined fluorometrically [17]. The method is based on the oxidation of thiamine into red blood salt in alkaline in thiochrome, extraction of the latter in an organic solvent, measuring the fluorescence intensity at spectrofluorimeter (wavelength of excitation $-360 \mathrm{~nm}$ and absorption $-430 \mathrm{~nm}$ ). Vitamin $B_{2}$ was determined by the fluorescence method using riboflavinconnecting apoprotein. The fluorescence intensity measured on spectrofluorimeter (wavelength of excitation $465 \mathrm{~nm}$ and absorption - $525 \mathrm{~nm}$ ) [18]. For determination of vitamin $B_{6}$ the sample extracted in the presence $2 \mathrm{~N}$ the sulfuric acid in the boiling water bath for $15 \mathrm{mi}-$ nutes. A solution was cooled and then added $1 \mathrm{ml}$ of $4 \mathrm{M}$ sodium acetate and filtered. In test tubes was placed $0,1 \mathrm{ml}$ of filtrate, add $4.9 \mathrm{ml}$ of $0,2 \mathrm{~N} \mathrm{HCl}$ and $0,4 \mathrm{ml}$ of isopropanol. Then it was cooled, $0,8 \mathrm{ml}$ potassium permanganate was added, and through 50 seconds $0,2 \mathrm{ml} \mathrm{so-}$ lution of hydrogen peroxide was added. The intensity of fluorescence was determined on spectrofluorometer (wavelength of excitation - $354 \mathrm{~nm}$ and absorption - $442 \mathrm{~nm}$ ). Definition of vitamin PP is based on the reaction that occurs in two stages:

a) the interaction of pyridine ring of nicotinic acid with bromicrodan;

b) formation of the painted derivative glutaconic aldehyde.

The intensity of color compound that was formed directly proportional to the mass fraction of vitamin PP, which is determined calorimetric [16]. 
5. The research results of the content change of the main vitamins in the biological activation of grain wheat, triticale and bare grain oats

The hydrothermal treatment regime - cold conditioning of grain for temperatures $12-16^{\circ} \mathrm{C}$ within $28-30$ hours is proposed. Under these conditions, humidity of grain increases about $30-35 \%$, which leads to activation of the enzyme complex, lower grain density and increase its specific volume. As a result of the intensification of enzymatic processes is partial hydrolysis of carbohy- drates and proteins, change conformation of protein macromolecules, activation of the synthesis of vitamins and vitamin-like substances.

For efficiency of biological process of activation and creation of optimum conditions of its carrying out indicators of physiologic value of grain are important: energy and ability of germination, viability of grain and sensibility to water.

The indicators of the physiological value of each batch of grain are investigated (Table 1).

Table 1

Indicators of physiological value of grain cereal cultures

\begin{tabular}{|c|c|c|c|}
\hline \multirow[t]{2}{*}{ Indicators } & \multicolumn{3}{|c|}{ Grain culture } \\
\hline & Wheat & Bare grain oats & Triticale \\
\hline Number of grains germinated in 3 days, pieces. & 486 & 482 & 498 \\
\hline Energy of germination, $\%$ & 97,2 & 96,4 & 99,6 \\
\hline Average square deviation & 0,85 & 1,13 & 0,98 \\
\hline Coefficient of a variation, $\%$ & 0,89 & 1,16 & 1,02 \\
\hline Amount of the grains which sprouted in the 5th days, pieces. & 495 & 490 & 100 \\
\hline Ability of germination, $\%$ & 99,0 & 98,0 & 100 \\
\hline Average square deviation & 0,28 & 0,42 & 0,28 \\
\hline Coefficient of a variation, $\%$ & 0,29 & - & 0,29 \\
\hline Viability, \% & 100,0 & 98,5 & 100 \\
\hline Average square deviation & 0 & 2,12 & 0,71 \\
\hline Coefficient of a variation, $\%$ & - & 2,29 & 0,72 \\
\hline
\end{tabular}

The conducted researches show that these consignments of grain are excellent quality, because values of energy germination and ability of germination exceed $95 \%$; the viability of the embryo, the potential germination capacity of grain to not less than $90 \%$.

Researches of phytin hydrolysis were conducted at different temperatures: 16 and $22{ }^{\circ} \mathrm{C}$. Change of phytin amount determined after soaking and sprouting grains for 30 hours (Table 2 ).

The conducted researches showed that during germination of grain is a significant phytin hydrolysis.
And at the lower temperatures hydrolysis is more actively.

Inositol, vitamin-like substance $\mathrm{B}_{8}$, contained in plants in the form of isomers and their methylated derivatives, among which myo-inositol. At grain germination calcium-magnesium salt of inozytphosphoric acid - phytin - decomposes on an inositol and a free orthophosphoric acid. So the next step of research was to determine of change of quantity in the course of biological activation of grain of wheat, triticale and bare grain oats, results are shown in Table 3.

Table 2

Effect of grain germination on the degree of phytin hydrolysis

\begin{tabular}{|c|c|c|c|c|c|c|c|c|c|}
\hline \multirow{3}{*}{ Indicator } & \multicolumn{3}{|c|}{ Grain of wheat } & \multicolumn{3}{|c|}{ Grain of triticale } & \multicolumn{3}{|c|}{ Grain of oats } \\
\hline & \multirow[t]{2}{*}{ Native } & \multicolumn{2}{|c|}{$\begin{array}{c}\text { Germinated at tem- } \\
\text { perature }\end{array}$} & \multirow[t]{2}{*}{ Native } & \multicolumn{2}{|c|}{$\begin{array}{l}\text { Germinated at tem- } \\
\text { perature }\end{array}$} & \multirow[t]{2}{*}{ Native } & \multicolumn{2}{|c|}{$\begin{array}{c}\text { Germinated at } \\
\text { temperature }\end{array}$} \\
\hline & & $16^{\circ} \mathrm{C}$ & $22^{\circ} \mathrm{C}$ & & $16^{\circ} \mathrm{C}$ & $22^{\circ} \mathrm{C}$ & & $16^{\circ} \mathrm{C}$ & $22^{\circ} \mathrm{C}$ \\
\hline $\begin{array}{l}\text { Dry sub- } \\
\text { stances } \\
\text { (DS), \% }\end{array}$ & 86 & 63,5 & 61,8 & 88,31 & 65,18 & 64,0 & 85,64 & 60,12 & 58,6 \\
\hline $\begin{array}{l}\text { Phytin, \% to } \\
\text { DS }\end{array}$ & 0,856 & 0,31 & 0,36 & 0,84 & 0,40 & 0,45 & 0,91 & 0,395 & 0,44 \\
\hline $\begin{array}{l}\text { Phytin, \% of } \\
\text { initial quan- } \\
\text { tity }\end{array}$ & 100 & 36,21 & 42,06 & 100 & 47.62 & 52,57 & 100 & 43,41 & 51,4 \\
\hline
\end{tabular}

Table 3

Effect of temperature conditions for germination synthesis of inositol in grain

\begin{tabular}{|l|c|c|c|}
\hline \multirow{2}{*}{\multicolumn{1}{|c|}{ Sample }} & \multicolumn{2}{c|}{ Sample inositol content in the grain, mg \% } \\
\cline { 2 - 4 } & Wheat & Triticale & Oats \\
\hline Native grain & 5,21 & 5,04 & 6,48 \\
\hline Germinated at a temperature of $16^{\circ} \mathrm{C}$ & 24,73 & 20,24 & 28,56 \\
\hline Germinated at a temperature of $22^{\circ} \mathrm{C}$ & 22,12 & 18,51 & 27,00 \\
\hline
\end{tabular}


It was established that during germination is an active synthesis of an inositol, at the lowest temperature as a result of more active hydrolysis of phytin, the bigger quantity of an inositol is formed.

Important task of preparation of raw materials is preservation and the maximum increase in content of vitamins. The change of vitamins content was investigated in the process of biological activation of grain; vitamins exhibit antioxidant properties - tocopherol, ascorbic acid, vitamin P (Table 4).

It is found that in biologically activated grain the amount of vitamin $\mathrm{C}$ increases in 2-3 times, a routine 2-2,5 times, significantly increases the content of tocopherols.

The complex of vitamins of group B is a valuable component of peripheral parts of grain. Changes of content of vitamins of group B and to a niacin in grain of wheat, triticale and bare grain oats in the course of a hydrothermal treatment are investigated (Table 5).
It is found that biologically activated grain number thiamine and riboflavin increases by $2-2,5$ times, compared to native grain; content of nicotinic acid and choline increased by $1,5-2$ times.

Table 4

The content of vitamins $\mathrm{C}, \mathrm{E}$, and $\mathrm{P}$ in grain

\begin{tabular}{|c|c|c|c|}
\hline $\begin{array}{c}\text { Grain cul- } \\
\text { ture }\end{array}$ & $\begin{array}{c}\text { Content of } \\
\text { vitamin P, } \\
\mathrm{mg} \%\end{array}$ & $\begin{array}{c}\text { Content of } \\
\text { vitamin E, } \\
\mathrm{mg} \%\end{array}$ & $\begin{array}{c}\text { Content of } \\
\text { vitamin C, } \\
\mathrm{mg} \%\end{array}$ \\
\hline \multicolumn{4}{|c|}{ Native grain } \\
\hline Wheat & $3,9 \pm 0,25$ & $0,34 \pm 0,02$ & $2,6 \pm 0,20$ \\
\hline Oat & $3,4 \pm 0,25$ & $0,21 \pm 0,02$ & $1,2 \pm 0,20$ \\
\hline Triticale & $4,5 \pm 0,25$ & $1,00 \pm 0,02$ & $2,3 \pm 0,20$ \\
\hline \multicolumn{4}{|c|}{ Grain after hydrothermal treatment } \\
\hline Wheat & $9,3 \pm 0,25$ & $10,73 \pm 0,02$ & $5,7 \pm 0,20$ \\
\hline Oat & $7,9 \pm 0,25$ & $9,26 \pm 0,02$ & $3,8 \pm 0,20$ \\
\hline Triticale & $9,2 \pm 0,25$ & $11,65 \pm 0,02$ & $4,1 \pm 0,20$ \\
\hline
\end{tabular}

Table 5

The content of vitamins of group B and niacin in grain

\begin{tabular}{|c|c|c|c|c|c|}
\hline \multirow{2}{*}{ Grain culture } & \multicolumn{5}{|c|}{ Content of vitamin, mg \% } \\
\cline { 2 - 6 } & $\mathrm{B}_{1}$ & $\mathrm{~B}_{2}$ & $\mathrm{PP}$ & $\mathrm{B}_{4}$ & $\mathrm{~B}_{6}$ \\
\hline \multicolumn{5}{|c|}{ Native grain } \\
\hline Wheat & $0,22 \pm 0,01$ & $0,12 \pm 0,02$ & $3,67 \pm 0,12$ & $92,0 \pm 0,20$ & $0,51 \pm 0,02$ \\
\hline Oat & $0,20 \pm 0,01$ & $0,13 \pm 0,02$ & $3,45 \pm 0,12$ & $98,0 \pm 0,20$ & $0,44 \pm 0,02$ \\
\hline Triticale & $0,29 \pm 0,01$ & $0,12 \pm 0,02$ & $3,8 \pm 0,12$ & $110,0 \pm 0,20$ & $0,65 \pm 0,02$ \\
\hline \multicolumn{7}{|c|}{ Grain after biological activation } \\
\hline Wheat & $0,35 \pm 0,01$ & $0,34 \pm 0,02$ & $4,33 \pm 0,12$ & $152,0 \pm 0,20$ & $0,68 \pm 0,02$ \\
\hline Oat & $0,31 \pm 0,01$ & $0,39 \pm 0,02$ & $4,10 \pm 0,12$ & $145,0 \pm 0,20$ & $0,38 \pm 0,02$ \\
\hline Triticale & $0,89 \pm 0,01$ & $0,16 \pm 0,02$ & $4,5 \pm 0,12$ & $175,0 \pm 0,20$ & $0,57 \pm 0,02$ \\
\hline
\end{tabular}

6. Discussion of research results of changes in the content of main vitamins in the biological activation of grain

The conducted researches showed that is a significant phytin hydrolysis is occurred during the biological activation of grain cereals, these results are consistent with practical data known from the work of G. Sripriya et al [19] with colleagues who say that soaking and sprouting help reduce anti-food substances in grains and seeds. But unlike existing data, researches show the degree of hydrolysis of phytin anti-mineral substances during germination grain of perspective cereal cultures of wheat, triticale and oats, which are important for increasing its nutritional value.

And it is investigated that at the lowest temperatures hydrolysis occurs more actively. Thus, germination temperature for $16{ }^{\circ} \mathrm{C}$ promoted reduce the number of phytin in wheat, triticale and oats, respectively $63,8 \%$, $52,4 \%$ and $55,6 \%$, and at a temperature of $22{ }^{\circ} \mathrm{C}$ much less - respectively $58 \%, 47,43 \%$ and $48,6 \%$.

The obtained results correlate with theoretical data, known from works of scientists who say that under the action of the enzyme phytase, that is activated in germinating grain, inozytphosphoric acid contained in a grain in the form of phytin, decomposes into inositol and free orthophosphoric acid [13]. But, unlike existing data, which only note the inositol is formed of phytin at ger- mination of grain, results demonstrate increasing the nutritional value of grain raw material due to a significant increase of inositol, which is required for normal growth and development of young organism; helps prevent disease alopecia.

The results of research content in main vitamins in biologically activated grain of cereal cultures are important from the point of view of increase the nutritional value. These data are consistent with researches of a number of scientists $[6,10]$, but the value of results is due to the definition of a full complex of vitamins in wheat, triticale and oats for the concrete technological parameters of its processing that enables the development of perspective technology of preparation of grain.

\section{Conclusions}

1. The hydrothermal treatment regime - cold grain conditioning, which promotes the increase of its nutritional value, is proposed.

2. The proposed method of preparation of grain raw materials allows to minimize of anti-mineral substance of phytin.

3. Biological activation of grain crops of wheat, triticale, bare grain oats gives a raw material for producing health foods with a high content of B vitamins, niacin, and those that exhibit antioxidant properties $\mathrm{E}$ and $\mathrm{C}$, substances with P-vitamin activity. 


\section{References}

1. Ozdorovitelnoe i dieticheskoe pitanie [Text] / V. I. Tsipriyana (Ed.). - Kyiv: Globus, 2001. - 336 p.

2. Vanhanen, V. V. Uchenie o pitanii [Text] / V. V. Vanhanen, V. D. Vanhanen. - Donetsk: Donechchina, 2000. - 352 p.

3. Yayting, M. Pitanie dlya detey i podrostkov [Text] / M. Yayting, T. Lobstayn. - Moscow: FAIR-PRESS, 2001. - 270 p.

4. Prykhod'ko, A. D. Proroshchene zerno, yak odyn iz chynnykiv vidtvornoyi zdatnosti ptytsi [Text] / A. D. Prykhod'ko // Rozvedennya i henetyka tvaryn. - 2000. - Vol. 33. - P. 111-113.

5. Shaskolskaya, N. D. Samaya poleznaya eda - prorostki [Text] / N. D. Shaskolskaya, V. V. Shaskolskyi. - Moscow: Azbuka, 2010. - 192 p.

6. Kim, Y. S. Comparison of the chemical components of buckwheat seeds and sprouts [Text] / Y. S. Kim, J. G. Kim, Y. S. Lee, I.-J. Kang // Journal of the Korean Society of Food Science and Nutrition. - 2005. - Vol. 34, Issue 1. - P. 81-86. doi: $10.3746 / \mathrm{jkfn} .2005 .34 .1 .081$

7. Rakcejeva, T. Gassy Ozone Effect on Quality Parameters of Flaxes Made from Biologically Activated Whole Wheat Grains [Text] / T. Rakcejeva, J. Zagorska, E. Zvezdina // International Journal of Biological, Biomolecular, Agricultural, Food and Biotechnological Engineering. - 2014. - Vol. 8, Issue 4. - P. 396-399.

8. Iordan, M. Changes in quality indices of wheat bread enriched with biologically active preparations [Text] / M. Iordan, A. Stoica, E. C. Popescu // Annals. Food science and technology. - 2013. - Vol. 14, Issue 2. - P. 165-170.

9. Mendez, F. I. Penetration of ozone into columns of stored grains and effects on chemical composition and processing performance [Text] / F. I. Mendez, D. E. Maier, L. J. Mason, C. P. Woloshuk // Journal of Stored Products Research. - 2003. Vol. 39, Issue 1. - P. 33-34. doi: 10.1016/s0022-474x(02)00015-2

10. Kim, S.-J. Comparison of phenolic compositions between common and tartary buckwheat (Fagopyrum) sprouts [Text] / S.-J. Kim, I. S. M. Zaidul, T. Suzuki, Y. Mukasa, N. Hashimoto, S. Takigawa et. al. // Food Chemistry. - 2008. - Vol. 110, Issue 4. P. 814-820. doi: 10.1016/j.foodchem.2008.02.050

11. Arutyunyan, T. V. Zminy lipidnoho skladu pshenytsi ta suputnikh rechovyn pry proroshchuvanni [Text] / T. V. Arutyunyan, F. F. Hladkyy, L. A. Danylova // Visnyk NTU «KhPI». - 2013. - Vol. 55. - P. 104-112.

12. Dudkin, M. S. Pischevyie volokna [Text] / M. S. Dudkin, N. K. Cherno, I. S. Kazanskaya, S. G. Vaynshteyn, A. M. Masik. - Kyiv: Urozhay, 1988. - 152 p.

13. Tashmenov, R. S. Analiz fitina v othodah proizvodstva risa [Text] / R. S. Tashmenov, K. A. Sabirov, A. Ya. Ibragimov, A. Sh. Karabaev // Himiko-farmatsevticheskiy zhurnal. - 1990. - Vol. 24, Issue 10. - P. 86-87.

14. Antonyuk, V. O. Oderzhannya fitinu ta lektinu iz zarodkiv pshenitsi v odnomu tehnologichnomu tsikli [Text] / V. O. Antonyuk, L. Ya. Antonyuk // Ukrayins'kyi biokhimichnyi zhurnal. - 2000. - Vol. 72, Issue 2. - P. 97-99.

15. Meletyev, A. Ye. Tekhnokhimichnyy kontrol vyrobnytstva solodu, pyva i bezalkoholnykh napoyiv [Text] / A. Ye. Meletyev, S. R. Todosiychuk, V. M. Koshova. - Kyiv: Nova knyha, 2007. - 385 p.

16. Metodyi biohimicheskogo issledovoniya rasteniy [Text] / A. I. Ermakova (Ed.). - Leningrad: Agropromizdat, 1987. - 430 p.

17. Ostrovskyi, Yu. M. Eksperimentalnaya vitaminologiya [Text] / Yu. M. Ostrovskyi, V. B. Spyrychev, Y. Y. Matusys et. al.; Yu. M. Ostrovskyi (Ed.). - Minsk: Nauka i tehnika, 1979. - 552 p.

18. Kodentsova, V. M. Vyidelenie riboflavinsvyazyivayuschego apobelka iz belka kurinyih yaits i ego ispolzovanie dlya opredeleniya riboflavina v biologicheskih obraztsah [Text] / V. M. Kodentsova // Prikladnaya biohimiya i mikrobiologiya. - 1994. Vol. 30, Issue 4-5. - P. 603-609.

19. Sripriya, G. Changes in carbohydrate, free amino asids, organic acids, phytate and HCL extractability of minerals during germination and fermentation of finger millet (Ellusine coracana) [Text] / G. Sripriya, U. Antony, T. S. Chandra // Food Chemistry. 1997. - Vol. 58, Issue 4. - P. 345-350. doi: 10.1016/s0308-8146(96)00206-3

Рекомендовано до публікації д-р техн. наук, професор Сімахіна Г. О. Дата надходження рукопису 26.05.2017

Svitlana Bazhay-Zhezherun, PhD, Associate Professor, Department of Wellness Products Technology, National University of Food Technologies, Volodymyrska str., 68, Kyiv, Ukraine, 01601

E-mail: LanaNEW_1@ukr.net

Ludmyla Bereza-Kindzerska, PhD, Department of Biochemistry and Environmental Control, National University of Food Technologies, Volodymyrska str., 68, Kyiv, Ukraine, 01601

E-mail: kinlud@ukr.net

Olga Togachynska, PhD, Associate Professor, Department of Biochemistry and Environmental Control, National University of Food Technologies, Volodymyrska str., 68, Kyiv, Ukraine, 01601

E-mail: tytyn29@ukr.net 


\section{ABSTRACT\&REFERENCES}

\section{DOI: 10.15587/2313-8416.2017.107557 \\ BRAND AND BRANDING IDENTIFICATION IN PROFES- SIONAL ACTIVITY OF ARCHITECT}

\section{p. 6-8}

Marina Pominchuk, Assistant, Department of Architectural Fundamentals, Kharkiv National University of Civil Engineering and Architecture, Sumska str., 40, Kharkiv, Ukraine, 61002

E-mail: pominchuk.marina@gmail.com

ORCID: http://orcid.org/0000-0001-8659-8821

The article classifies the definitions of brand and lists its structural components. Branding in architecture is considered in three aspects: in the field of commercial real estate, architect - brand, and city branding. Branding in the field of commercial real estate requires the most attentive attitude to the brand on the part of the architect. The phenomenon of "architect - brand" is interesting from a social point of view. City branding is seen in the European experience Keywords: brand, branding, architectural design, individualization, identity, brand conception, city branding, globalization

\section{References}

1. Vasilevsky, V. V. (2006). Marketing strategy of the shopping center: from shopping to happing. Commercial Rent, 12 (28), 36-39.

2. Tamberg, V., Badin, A. (2005). Brand. The fighting machine of business. Moscow: New branding, 240.

3. Ellwood, A. (2003). Basics of branding. Moscow: Publishing House Grand Fair Press, 336.

4. Chicherova, L. (2007). Profitable place: Brands in circulation. Vedomosti, 72 (1846). Available at: http://franshiza.ru/article/ $\mathrm{read} /$ dohodnoe_mesto/

5. Mommaas, H. (2003). City branding. The Necessity of Socio-cultural goals. City branding. Image building \& building images. Rotterdam: Nai Uitgevers, 34-45.

6. Florian, B. (2003). The City as a Brand. Orchestrating a unique experience. City branding. Image building $\&$ building images. Rotterdam: Nai Uitgevers, 20-31.

7. Shipova, I. (2007). Offices in postindustrial Europe: the case of Germany. Project Russia. A business, 4, 74.

8. Ryabokobylko, S. (2007). The aesthetic project is always successful. Project Russia. A business, 46.

9. Bronovitskaya, A. (2008). Hotels: features of the genre Project Russia. Hospitality, 1.

10. Nikolina, P. (2007). The Milan boom. From the ethics of production to the aesthetics of consumption. Project International, 18 .

11. Speaks, M. (2003). Individualization without identity. City branding. Image building \& building images. Rotterdam: Nai Uitgevers, 50-65.

DOI: $10.15587 / 2313-8416.2017 .107537$

\section{RESEARCH OF FUNCTIONING OF NATIONAL MARKETS OF SECURITIES IN THE WORLD FINANCIAL CENTERS}

$$
\text { p. 9-15 }
$$

Yuliya Kovalenko, Doctor of Economic Sciences, Professor, Department of Financial Markets, University of State Fiscal Service of Ukraine, Universytetska str., 31, Irpin, Kyiv region, Ukraine, 08201 E-mail: kovalenko0202@ukr.net

ORCID: http://orcid.org/0000-0002-5678-3185
Tatiana Bilovus, Postgraduate student, Academy of Financial Management, Druzhby Narodiv blvd., 38, Kyiv, Ukraine, 01014

E-mail: tatianabilovus@ukr.net

ORCID: http://orcid.org/0000-0003-2542-5614

The article investigates the world financial centers and rating of leaders among them. It is proved that an important component of the world financial centers is the developed securities markets, in particular the London, New York, and Tokio, which have a significant share of world capital. The current state, problems and tendencies of the securities market development in Ukraine are analyzed

Keywords: world financial center, market of securities, stock exchange, index

\section{Reference}

1. Kovalenko, Yu. M. (2013). Institutionalization of financial sector. Irpin: NUDPSU, 608.

2. Shuba, M. V. (2014). Global financial centers - «heart» of the global financial market. Bulletin KNU named after V. N. Karazin, 1 (3), 8588 .

3. Scherban, O. D. (2013). Determining the structure of modern international financial market. Scientific Journal: Finance, banks, investment, 2, 64-68.

4. Redzyuk, E. (2015). Impact of stock markets of developed countries and developing countries, international financial and investment processes. Bulletin of the National Bank of Ukraine, $5,50-56$.

5. GFCI - Global Financial Centres Index. Availble at: http://www.zyen.com/research/gfci.html.

6. Financial Portal of the Ministry of Finance of Ukraine. Available at: http://index.minfin.com.ua/stock/

7. Kovalenko, Yu. M., Vorobei, A. S. (2015). Functioning of the stock market of Ukraine in modern conditions. Collection of scientific papers of the National University of the State Tax Service of Ukraine, 1, 122-133.

8. National Securities and Stock Market Commission. Available at: https://www.nssmc.gov.ua

9. PFTS Stock Exchange. Available at: http://www.pfts.ua

10. Ukrainian Exchange. Available at: http://www.ux.ua/ru/ index/ux

DOI: 10.15587/2313-8416.2017.107108

\section{COMPARISON OF SPECIFICITY AND FEATURES OF DEFINITION OF MARKETING AND BRANDING IN THE FIELD OF TOURISM AND HOTEL BUSINESS}

$$
\text { p. 15-18 }
$$

Olena Uhodnikova, $\mathrm{PhD}$, senior lecturer, Departmentof Tourism and Hospitality business, O. M. Beketov National University of Urban Economy in Kharkiv, M. Bazhanov str., 17, Kharkiv, Ukraine, 61002

E-mail: Ugodnikova16@gmail.com

ORCID: http://orcid.org/0000-0003-2218-0041

Anna Ziglo, $\mathrm{PhD}$, associate professor, Department of technologies of building production and building materials, O. M. Beketov National University of Urban Economy in Kharkiv, M. Bazhanov str., 17, Kharkiv, Ukraine, 61002

E-mail: anna.baranova@kname.edu.ua ORCID: http://orcid.org/0000-0001-5097-5285 